\title{
Effects of Passivators on Artemisia selengensis Yield and Cd Stabilization in a Contaminated Soil
}

\author{
Di Zhang*, Aifang Ding, Ting Li, Xiaoxia Wu \\ Nanjing Xiaozhuang University, Nanjing 211171, Peoples’ Republic of China
}

Received: 22 July 2020

Accepted: 30 August 2020

\begin{abstract}
Cadmium $(\mathrm{Cd})$ contamination in agricultural soils has caused serious environmental risks and public health concern; possible eco-friendly immobilization technologies are required to reduce $\mathrm{Cd}$ accumulation. A set of pot experiments was carried out with two genotypes of Artemisia selengensis grown in a Cd-contaminated soil, which was amended with hydrated lime (L), diatomite (D) and biochar (B), either alone or in combination, to investigate the impacts of these passivators on bioavailability and mobility of $\mathrm{Cd}$ in soil and crops. The results demonstrated that hydrated lime and diatomite significantly promoted the immobilization of soil $\mathrm{Cd}$ and decreased the accumulation of $\mathrm{Cd}$ in Artemisia selengensis, and biochar significantly increased Artemisia selengensis yield. The residual fraction of Cd was increased 1.35 1.51 times for Fuqiu Artemisia selengensis and 0.97 1.05 times for Dayeqing Artemisia selengensis, respectively, under the hydrated lime (L) and hydrated lime+diatomite+biochar (LDB) treatments. Correspondingly, Artemisia selengensis yields were increased by $44.45 \% \sim 52.50 \%$ and $37.91 \% \sim 43.36 \%$, respectively, in the treatments of biochar (B) and combination amendment (LDB). The results indicate that combination passivators (LDB) are recommended in practical applications, given their high efficiency for soil remediation and potential benefits. Fuqiu Artemisia selengensis, rather than Dayeqing Artemisia selengensis, are suggested to be employed for plants in mildly Cd-contaminated soil to ensure vegetable safety. These findings provide stronger evidence and theoretical support for in situ remediation of Cd-contaminated soil.
\end{abstract}

Keywords: passivator, chemical immobilization, bioavailability, Cadmium, Artemisia selengensis

\section{Introduction}

Heavy metal contamination has become a global environmental problem in the last few years, which

*e-mail: zhangdi@njxzc.edu.cn

may be caused by rapid industrial development and agricultural activities [1]. Cd accumulation in Chinese agricultural soils is very serious and widespread. This is a problem of great concern because of the elevated Cd uptake in crops through food chain transfer, which poses risks to human health [2]. Therefore, it is urgently needed to take measures to remediate $\mathrm{Cd}$-contaminated soil. For this purpose, various remediation techniques 
such as physical approaches, chemical immobilization and phytoextraction, have been explored [3-4]. Chemical immobilization technologies to remediate $\mathrm{Cd}$ pollution in agricultural soils have received broad attention because of their cost-effectiveness, short time period required for remediation and minor impact on the ecological environment [5].

The key factor of in situ chemical immobilization of heavy metals is the selection of passivators. Many passivators have been developed, such as alkaline materials, organic materials and clay minerals. Hydrated lime, as the most widely adopted amendment, can reduce heavy metal solubility and increase metal sorption to the soil by increasing soil $\mathrm{pH}$, resulting in a reduction in metal bioavailability and a decrease in metal uptake by crops $[4,6]$. Organic materials have plenty of biochars, the reactive groups of biochar can provide large areas and high porosities to ameliorate the toxicity of heavy metal fractions [7-8]. Compared to other organic materials, biochar is attractive in quality and inexpensive to remediate heavy metal contamination; however, the immobilizing effect depended on soil conditions, such as CEC and $\mathrm{pH}$ [910]. The clay mineral amendment such as diatomite belongs to an aluminosilicate mineral and has the characteristics of a large surface area and light porosity [11]. Diatomite could promote the immobilization of heavy metals by ion exchange and adsorption, thereby reducing heavy metal mobility and bioavailability. However, the bioavailability of heavy metal is not only related to the effects of passivators but also strongly linked to the plant source [12]. Moreover, a successful immobilization remediation technique for agricultural soils must maintain low bioavailability of heavy metals and could improve crop productivity effectively [3].

Artemisia selengensis, as medicinal vegetables, are favored because their nutrition and medicinal values are considerably higher than those of ordinary vegetables, and they have been widely planted in southern China in recent years. Previous studies have indicated that Artemisia selengensis have a strong ability to accumulate $\mathrm{Cd}$ and have low food safety as an edible vegetable [13]. A survey indicated that $\mathrm{Cd}$ concentrations in the edible part of Artemisia selengensis at all sampling points in the Dongting Lake region significantly exceeded the standard $\left(0.05 \mathrm{mg} \mathrm{kg}^{-1}\right)$ and posed a considerable threat to human health [14]. Li et al. [15] found that $\mathrm{Cd}$ concentrations in Artemisia selengensis exceeded the food safety standard when the soil Cd content was over $0.5 \mathrm{mg} \mathrm{kg}^{-1}$. Therefore, greater attention should be paid to the safety of Artemisia selengensis as edible stem and leaf vegetables in soils with high $\mathrm{Cd}$ concentrations.

To date, the majority of studies on this subject have examined the immobilization efficiency of passivators on the bioavailability of $\mathrm{Cd}$ in the soil-rice system. Notably few studies have used Artemisia selengensis to evaluate the passivating agent's efficiency in decreasing the phytoavailability of $\mathrm{Cd}$. Moreover, the effects of hydrated lime, diatomite and biochar alone on metal immobilization have been reported; however, the study of co-application of these amendments has been seldom investigated. A detailed study on how these amendments affect the bioavailability of $\mathrm{Cd}$ in contaminated soil and Artemisia selengensis is required, to decrease the toxicity of $\mathrm{Cd}$ to human health through food chains. Meanwhile, economical and environmentally friendly remediating agents have been found to broadly use for $\mathrm{Cd}$ contaminated agricultural soils.

Therefore, a set of pot experiments was carried out in a Cd-contaminated soil under the Artemisia selengensis system. Hydrated lime, diatomite and biochar were chosen as immobilizing agents to examine their effects on (1) the yield changes in two genotypes of local Artemisia selengensis, (2) the accumulation and phytotoxicity of $\mathrm{Cd}$ in two genotypes of local Artemisia selengensis, and (3) the immobilization of $\mathrm{Cd}$ in the soil-vegetable system.

\section{Materials and Methods}

\section{Experimental Materials}

Soil samples used in this study were collected from the surface layer $(0-20 \mathrm{~cm})$ of a vegetable field in the suburbs of Nanjing City, China. It is classified as yellowbrown soil based on Chinese Soil Taxonomy; while it would be Ferri-Udic Argosols according to the US Soil Taxonomy. Soil physicochemical characteristics were as follows: sand $7.51 \%$, silt $60.24 \%$ and clay $32.25 \%$, pH 6.15 , cation exchange capacity (CEC) $19.24 \mathrm{cmol} \mathrm{kg}^{-1}$ and soil organic carbon (SOC) $43.17 \mathrm{~g} \mathrm{~kg}^{-1}$. The total $\mathrm{Cd}$ content in the tested soil was $0.82 \mathrm{mg} \mathrm{kg}^{-1}$.

Three materials (hydrated lime, diatomite and biochar) were chosen as soil passivators. The passivators for hydrated lime $(\mathrm{L}, \mathrm{pH}=11.59)$ and diatomite $(\mathrm{D}$, $\mathrm{pH}=8.45)$ were directly purchased from a local company of Nanjing. The biochar was derived from rice straw that was prepared according to Zhang et al. [16]. The basic properties of biochar were $154.8 \mathrm{~g} \mathrm{~kg}^{-1} \mathrm{C}$, $10.25 \mathrm{~g} \mathrm{~kg}^{-1} \mathrm{~N}, 1.68 \mathrm{~g} \mathrm{~kg}^{-1} \mathrm{P}, \mathrm{pH}\left(\mathrm{H}_{2} \mathrm{O}\right)$ of 8.07 . The $\mathrm{Cd}$ content of biochar was $0.076 \mathrm{mg} \mathrm{kg}^{-1}$.

\section{Pot Experiment}

A set of pot experiments was performed in eight treatments: control (without passivators, designed CK), L (hydrated lime), D (diatomite), B (biochar), LD (1:1 hydrated lime: diatomite), LB (1:1hydrated lime: biochar), LB (1:1diatomite: biochar) and LDB (1:1:1 hydrated lime: diatomite: biochar). Each treatment was conducted in triplicate and randomly placed in the greenhouse. The application rate of single passivator was added to the soil at a rate of $5 \%(w / w$, on air-dry weight basis). For the treatment of two passivators, half of the amount of single passivator was applied, for the treatment of three passivators, one-third of the amount of single passivator was applied. Plastic pots measuring 
$30 \mathrm{~cm}$ in height and $30 \mathrm{~cm}$ in diameter were used in the pot experiments. $5 \mathrm{~kg}$ of dried soil was added to each pot. Urea, potassium dihydrogen phosphate and potassium sulfate were applied as basal fertilizer, and the application rate of $\mathrm{N}$ was $150 \mathrm{mg} \mathrm{kg}^{-1}, \mathrm{P}$ and $\mathrm{K}$ was $100 \mathrm{mg} \mathrm{kg}^{-1}$ and $100 \mathrm{mg} \mathrm{kg}^{-1}$, respectively. The passivators (including hydrated lime, diatomite and biochar) and chemical fertilizers were mixed thoroughly and applied to the soils.

Two genotypes of Artemisia selengensis, Fuqiu Artemisia selengensis and Dayeqing Artemisia selengensis, were employed in this study. The seedings were raised by cutting. When the true leaves growing on the stems of Artemisia selengensis measured approximately $1 \mathrm{~cm}$, the seedlings with the same growth were transplanted, with three plants per pot. Artemisia selengensis were watered according to the normal growth requirements during the experimental period. Artemisia selengensis were harvested 60 days after transplanting. Then, the aboveground parts (leaves and stems) and the roots were separated. The leaves, stems and roots were washed with running water, rinsed $3 \sim 4$ times with distilled water and followed by air-dried for $24 \mathrm{~h}$. The fresh weights of roots, stems and leaves were measured per pot and then they were homogenized by pulp refiner, respectively, and stored in plastic bottles prior to chemical analysis.

Soil samples of $0 \sim 20 \mathrm{~cm}$ were collected from the pots after removing Artemisia selengensis plants. The soil was air-dried and then ground to pass through a 10-mesh sieve for soil $\mathrm{pH}, \mathrm{CEC}$ and available $\mathrm{Cd}$ analysis. A subsample was ground further to sieve through a 100-mesh sieve to analyse SOC and $\mathrm{Cd}$ speciation.

\section{Chemical Analysis}

Soil $\mathrm{pH}$ was determined using soil to water ratio at 1:2.5 (w/v). Soil CEC was determined by $\mathrm{BaCl}_{2} / \mathrm{NH}_{4} \mathrm{Cl}$ compulsive exchange method as described by Gillman and Sumpter [17]. SOC was measured using a TOC (total organic carbon) analyzer (Multi N/C 3100, Analytik Jena, Germany). Soil available $\mathrm{Cd}$ was determined by $0.01 \mathrm{~mol} \mathrm{~L} \mathrm{~L}^{-1} \mathrm{CaCl}_{2}$ extraction as described by Houben et al. [18], and the redistribution of $\mathrm{Cd}$ in soil was determined using the European Community Bureau of Reference (BCR) sequential extraction method which was described in detail by $\mathrm{Xu}$ et al. [19]. Four different fractions designated by this method included: acid soluble, reducible, oxidizable, and residual fraction, of which the first three were extracted by $0.11 \mathrm{~mol} \mathrm{~L}^{-1} \mathrm{HAc}, 0.5 \mathrm{~mol} \mathrm{~L} \mathrm{~L}^{-1} \mathrm{NH}_{2} \mathrm{OH} \cdot \mathrm{HCl}$ and $1.0 \mathrm{~mol} \mathrm{~L}^{-1} \mathrm{NH}_{4} \mathrm{OAc}$, respectively, while the last was obtained by digesting the residual with $\mathrm{HNO}_{3}$ $\mathrm{HF}-\mathrm{HClO}_{4}$ mixture. Cd concentrations in soil samples were analyzed using inductively coupled plasma mass spectrometry (ICP-MS) (Agilent 7500, USA). A soil certified reference material (GBW07403, National Research Center for Certified Reference Materials,
China) was used to ensure the precision of the analytical procedure.

The Cd concentrations in Artemisia selengensis were measured using ICP-MS after digestion by $\mathrm{HNO}_{3} / \mathrm{H}_{2} \mathrm{O}_{2}$ according to the Determination of Cadmium in Foods, National Food Safety Standard of China (GB/T 5009.15-2014). The digestion process is as follows: samples of $0.5000 \mathrm{~g}$ were weighed into a polytetrafluoroethylene inner tank, and $4 \mathrm{~mL}$ of guaranteed pure $\mathrm{HNO}_{3}$ was added to incubate overnight, then $3 \mathrm{~mL}$ of $\mathrm{H}_{2} \mathrm{O}_{2}(30 \%)$ was added. The inner cover was closed and the stainless steel coat was tightened, then, the samples were placed into a constant temperature dryer and kept for $4 \sim 6 \mathrm{~h}$ at $140^{\circ} \mathrm{C}$. After that, the samples were placed onto an electricity plate and digested to the near dry. The samples were then diluted to $25 \mathrm{~mL}$ with $\mathrm{HNO}_{3}(1 \%)$. A plant certified reference material (GBW10015, National Research Center for Certified Reference Materials, China) was used to ensure the precision of the analytical procedure. The bioaccumulation factor (BAF) and the translocation factor (TF) were calculated as follows:

$$
\begin{gathered}
\mathrm{BAF}=\mathrm{C}_{\text {plant }} / \mathrm{C}_{\text {soil }} / \mathrm{C}_{\text {sol }} \\
\mathrm{TF}=\mathrm{C}_{\text {aboveground }} / \mathrm{Cbelowground}
\end{gathered}
$$

...where, $\mathrm{C}_{\text {plant }}$ is the $\mathrm{Cd}$ concentration in Artemisia selengensis $\left(\mathrm{mg} \mathrm{kg}^{-1}\right), \mathrm{C}_{\text {soil }}$ is the $\mathrm{Cd}$ concentration in soil $\left(\mathrm{mg} \mathrm{kg}^{-1}\right), \mathrm{C}_{\text {aboveground }}$ is the $\mathrm{Cd}$ concentration in Artemisia selengensis leaf and stem $\left(\mathrm{mg} \mathrm{kg}^{-1}\right)$, and $\mathrm{C}_{\text {belowground }}$ is the $\mathrm{Cd}$ concentration in Artemisia selengensis root $\left(\mathrm{mg} \mathrm{kg}^{-1}\right)$.

\section{Statistical Analysis}

All data were determined in duplicate. The means $(n=3)$ and standard deviations (S.D.) of the soil physicochemical properties, $\mathrm{Cd}$ concentrations and Artemisia selengensis yield were presented. One-way analysis of variance (ANOVA) was conducted using SPSS 20.0 statistical software. The least significant difference (LSD) test was carried out at the significance level of 0.05 .

\section{Results}

\section{Effects of Passivators on Artemisia selengensis Yield}

Fig.1 demonstrated that there were different effects of three passivators on edible part yields of Fuqiu Artemisia selengensis and Dayeqing Artemisia selengensis. Artemisia selengensis yields were the highest in the treatment of biochar (B), which were $44.45 \% \sim 52.50 \%$ higher than those in the control. However, there was no dramatically different in the treatments of B, LB and LDB in two genotypes of Artemisia selengensis. Compared to the control, the 

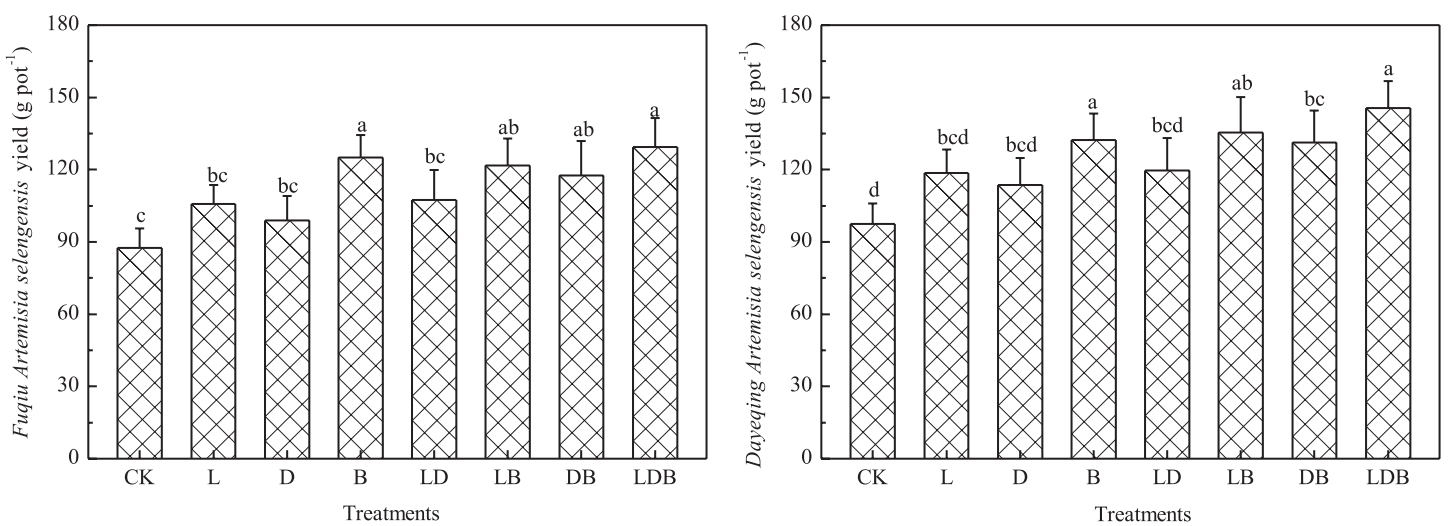

Fig. 1. Edible part yields of Fuqiu Artemisia selengensis and Dayeqing Artemisia selengensis grown in tested soil. CK, control; L, hydrated lime; D, diatomite; B, biochar; LD, hydrated lime + diatomite; LB, hydrated lime + biochar; DB, diatomite + biochar; $\mathrm{LDB}$, hydrated lime + diatomite + biochar. Values are mean $\pm \mathrm{SD}$, and different lowercase letters indicate significant difference among passivator treatments at $p<0.05$ level ( $\mathrm{n}=3$, LSD test).

effects of hydrated lime and diatomite on Artemisia selengensis yields were not significant.

\section{Effects of Passivators on Cd Bioaccumulation and Translocation in Artemisia selengensis}

The $\mathrm{Cd}$ concentrations in the roots, stems and leaves (fresh weight) were significantly reduced by the application of passivators in the two genotypes of Artemisia selengensis (Fig. 2). Compared to the control, the $\mathrm{Cd}$ concentrations in roots, stems and leaves decreased by $36.17 \% \sim 56.72 \%, 41.18 \% \sim 76.80 \%$ and $47.89 \% \sim 84.51 \%$, respectively, in the soil with Fuqiu Artemisia selengensis after the application of passivators. Similarly, for Dayeqing Artemisia selengensis, the $\mathrm{Cd}$ concentrations in roots, stems and leaves decreased by $25.69 \% \sim 57.93 \%, 36.26 \% \sim 71.32 \%$ and $43.16 \% \sim 73.54 \%$, respectively. Under the control treatment $(\mathrm{CK}), \mathrm{Cd}$ concentrations in stems (edible part of Artemisia selengensis) were $0.125 \mathrm{mg} \mathrm{kg}^{-1}$ and $0.182 \mathrm{mg} \mathrm{kg}^{-1}$ with Fuqiu Artemisia selengensis and Dayeqing Artemisia selengensis, respectively, exceeding the maximum limit $\left(0.05 \mathrm{mg} \mathrm{kg}^{-1}\right)$ of the Food Quality Standard of China (GB2762-2017). The $\mathrm{Cd}$ concentrations in the stems of Fuqiu Artemisia selengensis were below $0.05 \mathrm{mg} \mathrm{kg}^{-1}$ in the amendment treatments, except for the treatment of biochar addition (B). The minimum $\mathrm{Cd}$ concentrations were observed in the L and LDB treatments, which caused $76.80 \% \sim 78.4 \%$ reductions compared to the control. Similarly, $\mathrm{Cd}$ contents in the stems of Dayeqing Artemisia selengensis were below $0.05 \mathrm{mg} \mathrm{kg}^{-1}$ in the treatments of L, LD and LDB, and the $\mathrm{Cd}$ concentrations were decreased by $77.47 \%, 75.27 \%$ and $80.22 \%$, respectively.

The BAF of roots, stems and leaves was significantly decreased by the application of passivators in the two genotypes of Artemisia selengensis (Table 1). The lowest root, stem and leaf BAF was observed with the $\mathrm{L}$ and LDB passivators were $53.13 \% \sim 56.69 \%, 77.17 \% \sim 73.91 \%$ and $69.23 \% \sim 84.62 \%$ lower than the control value with
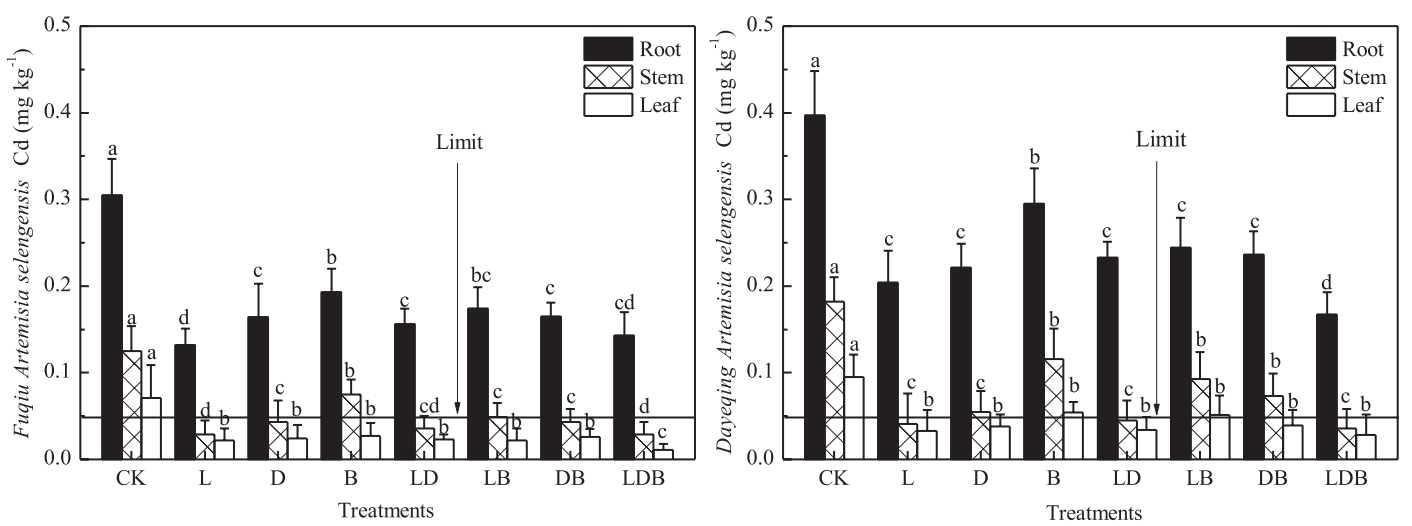

Fig. 2. Cd concentrations of Fuqiu Artemisia selengensis and Dayeqing Artemisia selengensis grown in tested soil. CK, control; L, hydrated lime; D, diatomite; B, biochar; LD, hydrated lime + diatomite; LB, hydrated lime + biochar; DB, diatomite + biochar; LDB, hydrated lime + diatomite + biochar. Values are mean $\pm \mathrm{SD}$, and different lowercase letters indicate significant difference among passivator treatments at $p<0.05$ level ( $n=3$, LSD test). The horizontal line means that the maximum Cd limit of the National Food Quality Standard of the People's Republic of China is $0.05 \mathrm{mg} \mathrm{kg}^{-1}$ in vegetables. 


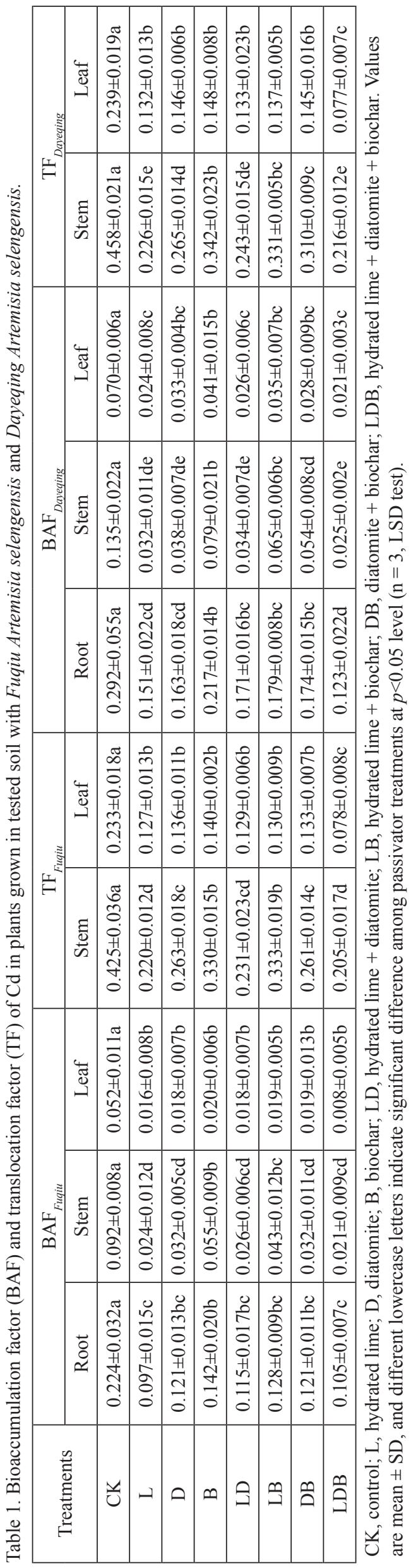

Fuqiu Artemisia selengensis $(p<0.05)$, respectively. For Dayeqing Artemisia selengensis, the lowest root, stem and leaf BAF was also observed with hydrated lime (L) addition being $48.29 \%, 76.12 \%$ and $65.71 \%(p<0.05)$ of the highest value observed in the control, respectively. The translocation factor of $\mathrm{Cd}$ in the amended soil with two genotypes of Artemisia selengensis had a significant decreasing effect $(p<0.05)$ over the control (Table 1).

\section{Effects of Passivators on Soil Properties}

Table 2 indicated that significant changes were observed in soil chemical properties after the application of different passivators. Compared to the control, soil $\mathrm{pH}$ in the tested soil with two genotypes of Artemisia selengensis was significantly increased with the addition of passivators $(p<0.05)$. The highest value of soil $\mathrm{pH}$ was found in the $\mathrm{L}$ treatment among all the passivator treatments. Soil $\mathrm{pH}$ was increased over the control by 0.37 and 0.33 units in the tested soil with Fuqiu Artemisia selengensis and Dayeqing Artemisia selengensis, respectively. The application of biochar (B) led to significantly higher soil SOC concentration than that in the control $(p<0.05)$ with Fuqiu Artemisia selengensis. However, the soil SOC concentrations of all treatments with biochar addition (B, LB, DB and LDB) were significantly higher than that of other treatments with Dayeqing Artemisia selengensis. No significant difference was found in CEC contents among all treatments. The maximum soil $\mathrm{CEC}$ was found in the LDB treatment.

\section{Effects of Passivators on $\mathrm{CaCl}_{2}-\mathrm{Cd}$ Concentration}

The application of passivators effectively reduced soil $\mathrm{Cd}$ bioavailability (Fig. 3). Soil $\mathrm{CaCl}_{2}-\mathrm{Cd}$ concentrations in all passivator treatments were significantly reduced in the two genotypes of Artemisia selengensis, particularly in the $\mathrm{L}$ treatment. Compared with the control, the $\mathrm{L}$ and LDB treatments with Fuqiu Artemisia selengensis decreased the $\mathrm{CaCl}_{2}-$ Cd concentration by $37.50 \%$ and $29.17 \%$, respectively. Similarly, the L and LDB treatments with Dayeqing Artemisia selengensis decreased the $\mathrm{CaCl}_{2}-\mathrm{Cd}$ concentration by $50.0 \%$ and $45.45 \%$, respectively. There was no significant difference in the treatments of $\mathrm{D}, \mathrm{B}$, $\mathrm{LB}$ and DB. In general, soil $\mathrm{CaCl}_{2}-\mathrm{Cd}$ concentrations with Fuqiu Artemisia selengensis were lower than those with Dayeqing Artemisia selengensis.

\section{Effects of Passivators on Soil Cd Distribution}

The application of passivators altered the fraction distribution of $\mathrm{Cd}$ in the soil with Fuqiu Artemisia selengensis and Dayeqing Artemisia selengensis (Fig. 4). The acid soluble fractions were reduced by 9.34\% 30.11\% for Fuqiu Artemisia selengensis and $13.33 \% \sim 30.77 \%$ for Dayeqing Artemisia selengensis. 
Table 2. Effects of passivators on soil pH, soil organic carbon (SOC) and CEC in the tested soil with Fuqiu Artemisia selengensis and Dayeqing Artemisia selengensis

\begin{tabular}{|c|c|c|c|c|c|c|}
\hline \multirow{2}{*}{ Treatments } & \multicolumn{3}{|c|}{ Fuqiu Artemisia selengensis } & \multicolumn{3}{c|}{ Dayeqing Artemisia selengensis } \\
\cline { 2 - 7 } & $\mathrm{pH}$ & SOC & CEC & $\mathrm{pH}$ & SOC & CEC \\
\hline CK & $6.16 \pm 0.03 \mathrm{e}$ & $43.55 \pm 3.06 \mathrm{~b}$ & $19.33 \pm 2.01 \mathrm{a}$ & $6.15 \pm 0.06 \mathrm{c}$ & $43.45 \pm 3.11 \mathrm{~b}$ & $19.79 \pm 2.19 \mathrm{a}$ \\
\hline L & $6.53 \pm 0.04 \mathrm{a}$ & $42.84 \pm 2.83 \mathrm{~b}$ & $22.21 \pm 2.04 \mathrm{a}$ & $6.48 \pm 0.11 \mathrm{a}$ & $43.31 \pm 2.07 \mathrm{~b}$ & $23.71 \pm 1.50 \mathrm{a}$ \\
\hline D & $6.38 \pm 0.05 \mathrm{bcd}$ & $42.97 \pm 3.32 \mathrm{~b}$ & $20.49 \pm 1.64 \mathrm{a}$ & $6.32 \pm 0.06 \mathrm{~b}$ & $43.51 \pm 3.98 \mathrm{~b}$ & $22.73 \pm 1.51 \mathrm{a}$ \\
\hline B & $6.29 \pm 0.03 \mathrm{~d}$ & $54.23 \pm 4.69 \mathrm{a}$ & $20.68 \pm 1.32 \mathrm{a}$ & $6.29 \pm 0.06 \mathrm{bc}$ & $56.87 \pm 5.75 \mathrm{a}$ & $20.41 \pm 1.95 \mathrm{a}$ \\
\hline LD & $6.42 \pm 0.05 \mathrm{~b}$ & $43.42 \pm 3.22 \mathrm{~b}$ & $22.57 \pm 3.67 \mathrm{a}$ & $6.38 \pm 0.05 \mathrm{ab}$ & $44.25 \pm 2.33 \mathrm{~b}$ & $22.48 \pm 3.18 \mathrm{a}$ \\
\hline LB & $6.39 \pm 0.09 \mathrm{bc}$ & $47.09 \pm 6.01 \mathrm{ab}$ & $20.60 \pm 2.93 \mathrm{a}$ & $6.31 \pm 0.08 \mathrm{~b}$ & $50.29 \pm 2.73 \mathrm{a}$ & $22.64 \pm 2.56 \mathrm{a}$ \\
\hline DB & $6.31 \pm 0.03 \mathrm{~cd}$ & $49.41 \pm 3.82 \mathrm{ab}$ & $21.47 \pm 2.06 \mathrm{a}$ & $6.33 \pm 0.06 \mathrm{~b}$ & $50.91 \pm 4.81 \mathrm{a}$ & $21.61 \pm 0.14 \mathrm{a}$ \\
\hline LDB & $6.36 \pm 0.06 \mathrm{bc}$ & $50.27 \pm 5.29 \mathrm{ab}$ & $22.94 \pm 2.31 \mathrm{a}$ & $6.41 \pm 0.13 \mathrm{ab}$ & $54.85 \pm 2.36 \mathrm{a}$ & $23.76 \pm 1.73 \mathrm{a}$ \\
\hline
\end{tabular}

CK, control; L, hydrated lime; D, diatomite; B, biochar; LD, hydrated lime + diatomite; LB, hydrated lime + biochar; DB, diatomite + biochar; LDB, hydrated lime + diatomite + biochar. Values are mean $\pm \mathrm{SD}$, and different lowercase letters indicate significant difference among passivator treatments at $p<0.05$ level ( $\mathrm{n}=3$, LSD test).

The percentage of the reducible fractions increased from $11.03 \%$ to $44.78 \%$ in the soil with Fuqiu Artemisia selengensis and from $11.21 \%$ to $29.80 \%$ with Dayeqing Artemisia selengensis. In the $\mathrm{L}$ and LDB treatments, the residual fractions of $\mathrm{Cd}$ were increased 1.35 1.51 times for Fuqiu Artemisia selengensis and 0.97 1.05 times for Dayeqing Artemisia selengensis. These results demonstrate that some of the acid soluble and reducible $\mathrm{Cd}$ fractions were transformed into oxidizable and residual fractions, indicating a decrease in their bioavailability.

\section{Discussion}

The purpose of this research was to examine the impact of different passivators on Artemisia selengensis yield and $\mathrm{Cd}$ accumulation in contaminated soil and plants. This study found that the effects of biochar in increasing Artemisia selengensis yield were better than those of hydrated lime and diatomite. Biochar is a net source of organic matter, N, P and K, which can provide multiple nutrients to plant and improve soil structure to promote plant growth [20-21]. Previous study found that hydrated lime could effectively increase crop yield in severely acidic soils [3]; but the tested soil is slightly acidic in this research and the yield-increasing effect of hydrated lime is thus limited. Except for crop biomass, heavy metal bioavailability in the edible part of crops is an important indicator for assessing efficiency in the in situ immobilization [6]. In this study, the application of the three passivators decreased $\mathrm{Cd}$ concentrations in the roots, stems and leaves of Artemisia selengensis at different degrees. The effects of hydrated lime and diatomite in reducing $\mathrm{Cd}$ accumulation of Artemisia selengensis were stronger than those with biochar
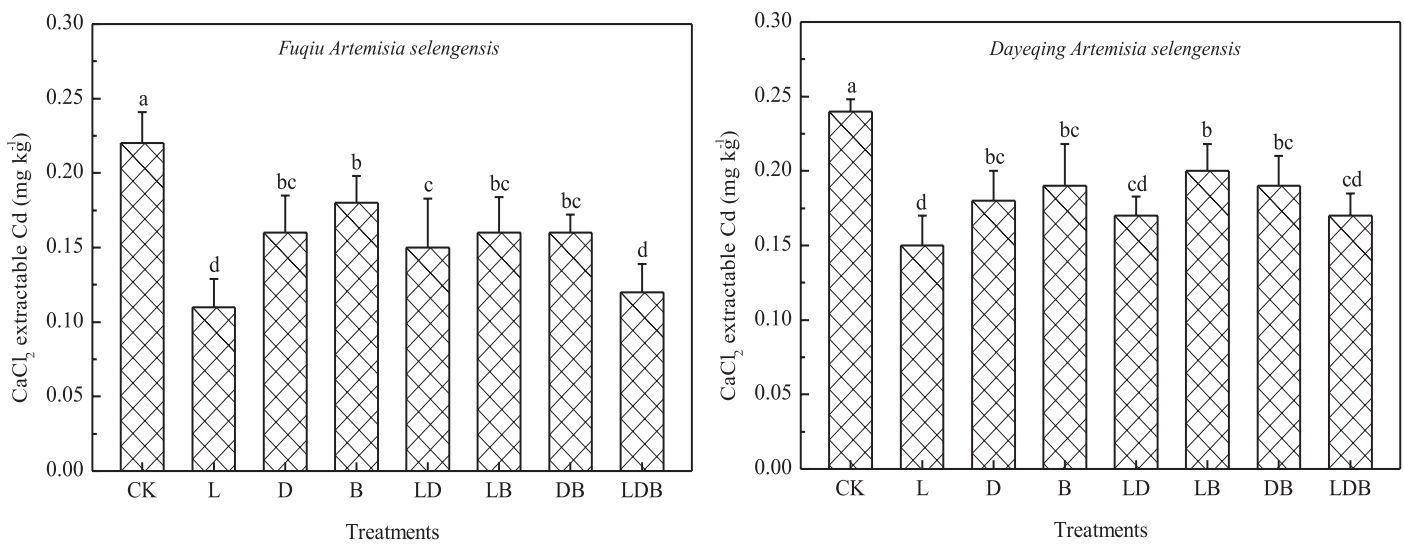

Fig. 3. Concentrations of available $\mathrm{Cd}$ in soils with Fuqiu Artemisia selengensis and Dayeqing Artemisia selengensis. CK, control; L, hydrated lime; D, diatomite; B, biochar; LD, hydrated lime + diatomite; LB, hydrated lime + biochar; DB, diatomite + biochar; $\mathrm{LDB}$, hydrated lime + diatomite + biochar. Values are mean $\pm \mathrm{SD}$, and different lowercase letters indicate significant difference among passivator treatments at $\mathrm{p}<0.05$ level $(\mathrm{n}=3, \mathrm{LSD}$ test). 
(Fig. 2). The reduced uptake of $\mathrm{Cd}$ by the Artemisia selengensis grown in the soils applied with passivators was associated with the enhancement of soil $\mathrm{pH}$ and depended on the available $\mathrm{Cd}$ concentration in soils (Fig. 3). Hydrated lime significantly increased soil $\mathrm{pH}$ compared to other passivators (Table 1), decreased accumulation of $\mathrm{Cd}$ in soil and restrained $\mathrm{Cd}$ uptake by plants. Diatomite plays an important part in surface complexation because of its higher specific surface, which can promote metal sorption via surface complexation processes [22-23]. Biochar decreased the $\mathrm{Cd}$ concentration, most likely due to adsorption by soil organic matter and strong inner-sphere complexation with Cd [24-25]. However, compared with employing a single amendment, the application of mixed passivators appears to be more efficacious in reducing $\mathrm{Cd}$ accumulation in the edible part of Artemisia selengensis (Fig. 2) and improving the growth of two genotypes of Artemisia selengensis (Fig. 1). This finding may be ascribed to the increment of soil nutrients and the alleviation of Cd stress.

The translocation of $\mathrm{Cd}$ in plants organ plays a key role in the accumulation of $\mathrm{Cd}$ in edible part of Artemisia selengensis. In our study, Cd concentrations in different tissues of two genotypes of Artemisia selengensis decreased in the order of root $>$ stem $>$ leaf, and the translocation factor (TF) of $\mathrm{Cd}$ was lower than 0.4 . These results indicated that the $\mathrm{Cd}$ absorbed by the Artemisia selengensis plants from the soil was mainly concentrated in the root system, and the amount of $\mathrm{Cd}$ transported to the aerial part was less than that in the underground part, which is similar to the conclusion of other studies $[15,26]$. The reason for this finding may be that $\mathrm{Cd}$ could accumulate in the cell walls, vacuoles and nuclei of roots in the insoluble fraction. Moreover, the migration and accumulation of $\mathrm{Cd}$ in roots, stems and leaves were in similar forms, and the ability of the former organ to immobilize or intercept $\mathrm{Cd}$ has a great influence on the accumulation of $\mathrm{Cd}$ in the next organ [21]. Cd concentrations in the edible part of Artemisia selengensis are closely related to food safety and human health. According to the results, Cd concentrations in the edible part of Fuqiu Artemisia selengensis met the food safety standard $\left(0.05 \mathrm{mg} \mathrm{kg}^{-1}\right)$ in the amendment treatments except for biochar addition, while $\mathrm{Cd}$ concentrations in Dayeqing Artemisia selengensis were below $0.05 \mathrm{mg} \mathrm{kg}^{-1}$ only in L, LD and LDB treatments (Fig. 2). These findings may be correlated to the lower $\mathrm{Cd}$ accumulation ability of Fuqiu Artemisia selengensis than Dayeqing Artemisia selengensis after passivating agents' application, and previous research has identified large genotypic differences in $\mathrm{Cd}$ accumulation and translocation among Artemisia selengensis species [15]. Meanwhile, there are complex and intensive interactions among soil organisms, roots and heavy metals, resulting in redistribution of $\mathrm{Cd}$ fractions in the rhizosphere soil [27-28]. Therefore, Fuqiu Artemisia selengensis should be employed as a plant in mildly Cd-contaminated soil to decrease the risk of $\mathrm{Cd}$ contamination in vegetables.

Researches on chemical immobilization need to pay more attention to the changes of soil properties and $\mathrm{Cd}$ accumulation in contaminated soil after the application of passivators, which may affect the accumulation of $\mathrm{Cd}$ in crops. In present study, hydrated lime, diatomite and biochar significantly affected soil physicochemical properties and $\mathrm{Cd}$ bioavailability. Previous studies have reported that soil $\mathrm{pH}$, SOC and CEC are important factors affecting heavy metal bioavailability, especially soil $\mathrm{pH}$, which plays the most important role in controlling $\mathrm{Cd}$ availability compared with other soil properties [29-30]. Soil $\mathrm{pH}$ had a prominent effect on heavy metal speciation due to its dissolution and precipitation [8, 31]. The increase in soil $\mathrm{pH}$ led to the generation of more negatively charged sorption sites and the precipitation of $\mathrm{Cd}$ as $\mathrm{CdCO}_{3}$ or $\mathrm{Cd}(\mathrm{OH})_{2}$ [32]. Previous studies demonstrated that there was significantly negatively correlated between soil $\mathrm{pH}$ and $\mathrm{CaCl}_{2}$ extractable $\mathrm{Cd}$ [33-34]. In this research, the soil $\mathrm{CaCl}_{2}-\mathrm{Cd}$ was notably reduced in the amended soil, particularly in the treatment of hydrated lime addition, possibly because the added hydrated lime has high $\mathrm{pH}$ and promotes an increase in soil $\mathrm{pH}$. In addition, increasing $\mathrm{CEC}$ and SOC played an important part in enhancing soil $\mathrm{Cd}$ immobilization and reducing the bioavailability of $\mathrm{Cd}$. This is agreed with Hoben et al. [19], who found there were strong and significant
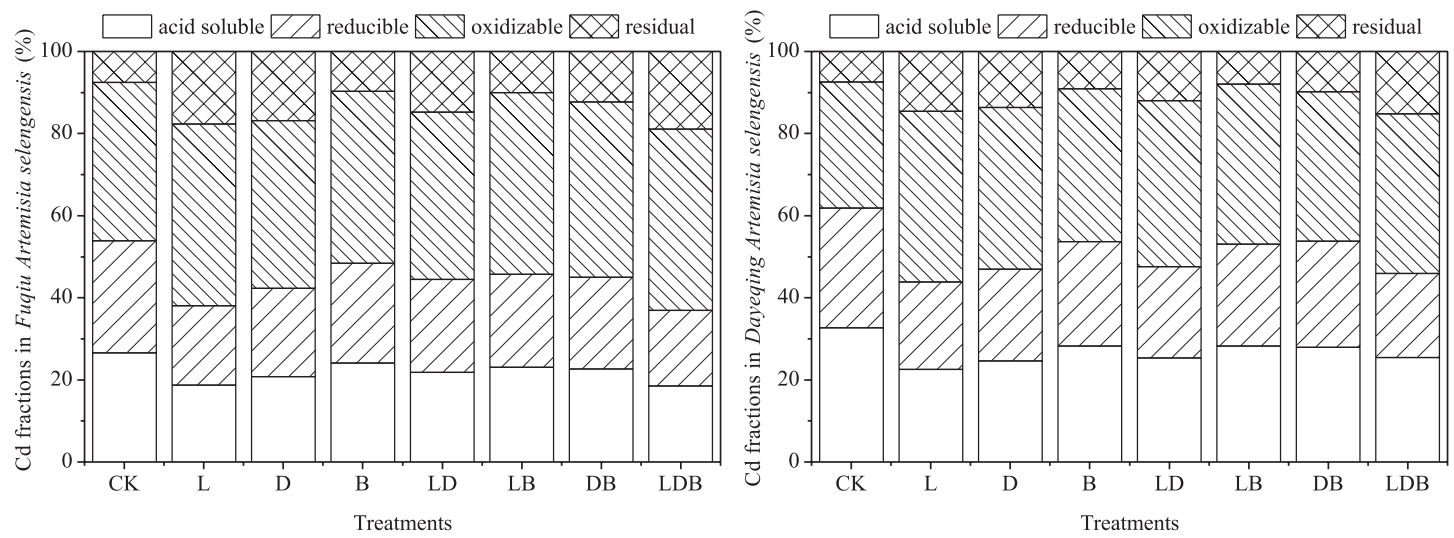

Fig. 4. Cd chemical fractions in tested soil with Fuqiu Artemisia selengensis and Dayeqing Artemisia selengensis. 
negative correlations among available $\mathrm{Cd}$ concentration and SOC and CEC. Metal sequential extraction technique is commonly regarded as the assessment method to evaluate the remediation efficacy, because the bioavailability of soil heavy metals varies with their chemical speciation [35-36]. Our results indicated that the speciation of $\mathrm{Cd}$ was clearly changed by the addition of passivators. Different passivators exhibited different $\mathrm{Cd}$ immobilization strengths, and the application of hydrated lime changed the soil $\mathrm{Cd}$ from the acid-soluble fraction to more stabilized residual fractions than other passivators (Fig. 4). This finding is in agreement with the decreased $\mathrm{Cd}$ uptake by Artemisia selengensis (Fig. 2).

The chemical remediation of Cd-contaminated soil requires not only technological advances but also economic efficiency evaluations and environmental friendliness. Although price of hydrated lime is relatively low and the remediation effect for $\mathrm{Cd}$ is quite well, long-term application may pose a potential risk to the environment, such as soil compaction and hazardous substance accumulation [37], its application in large scale is hindered. The prices of diatomite and biochar are 2 2.5 times higher than that of hydrated lime, and the remediation efficiency of diatomite or biochar alone on $\mathrm{Cd}$ is lower than hydrated lime. Therefore, it is not recommended that diatomite and biochar are used alone for remediation of $\mathrm{Cd}$-contaminated soil. In most cases, the environmental risks and economic cost may be controlled by the application of suitable combined passivators; therefore, developing combined passivators was regarded as an effective way to immobilize soil heavy metal. Furthermore, the remediation efficiency and vegetable growth need to be taken into account simultaneously [38-39]. In the present study, hydrated lime and diatomite could effectively decrease $\mathrm{Cd}$ accumulation in Artemisia selengensis and soil. Biochar may provide nutrients for Artemisia selengensis growth and have the ability to improve nutrient status. Meanwhile, biochar can increase soil $\mathrm{Cd}$ adsorbing capability due to a large specific surface area [40]. According to the present results, $\mathrm{Cd}$ concentrations ( 0.029 and $0.038 \mathrm{mg} \mathrm{kg}^{-1}$, respectively) in the edible part of Fuqiu Artemisia selengensis and Dayeqing Artemisia selengensis met the food safety standard $\left(0.05 \mathrm{mg} \mathrm{kg}^{-1}\right)$ in the amended treatment of hydrated lime + diatomite + biochar (LDB). Therefore, in the view of the effects of passivators on $\mathrm{Cd}$ accumulation and Artemisia selengensis yield, the cost as well as the potential benefits expected, combination passivators such as LDB are recommended for practical applications.

\section{Conclusions}

This study demonstrated that the application of hydrated lime and diatomite effectively immobilized $\mathrm{Cd}$, and biochar could significantly increase Artemisia selengensis yield. Combination passivators, such as hydrated lime + diatomite + biochar, are recommended in practical applications in Cd-contaminated soil, considering their low cost and high efficiency for remediation. Fuqiu Artemisia selengensis is suggested for plants in mildly Cd-contaminated soil to ensure vegetable safety compared to Dayeqing Artemisia selengensis. However, the immobilization effects of these applied passivators need to be evaluated under field conditions.

\section{Acknowledgements}

This research was supported by the Natural Science Research Project for Colleges and Universities of Jiangsu Province, China (19KJB610005) and the Scientific Research Project of Nanjing Xiaozhuang University (2018NXY52).

\section{Conflict of Interest}

The authors declare no conflict of interest.

\section{References}

1. ZHOU R., LIU X.C., LUO L., ZHOU Y.Y., WEI J.H., CHEN A.W., TANG L., WU H.P., DENG Y.C., ZHANG F.F., WANG Y.Y. Remediation of $\mathrm{Cu}, \mathrm{Pb}, \mathrm{Zn}$ and $\mathrm{Cd}$ contaminated agricultural soil using a combined red mud and compost amendment. Int. Biodeter. Biodegr. 118, 73, 2017.

2. KHAN A., KHAN S., KHAN M.A., QAMAR Z., WAQAS M. The uptake and bioaccumulation of heavy metals by food plants, their effects on plants nutrients, and associated health risk, a review. Environ. Sci. Pollut. Res. 22 (18), 13772, 2015.

3. GUO F.Y., DING C.F., ZHOU Z.G., HUANG G.X., WANG X.X. Effects of combined amendments on crop yield and cadmium uptake in two cadmium contaminated soils under rice-wheat rotation. Ecotoxicol. Environ. Saf. 148, 303, 2018.

4. BOLAN N., KUNHIKRISHNAN A., THANGARAJAN R., KUMPIENE J., PARK J., MAKINO T., KIRKHAM M.B., SCHECKEL K. Remediation of heavy metal(loid) s contaminated soils-to mobilize or to immobilize? J. Hazard. Mater. 266, 141, 2014.

5. XU C.B., QI J., YANG W.J., CHEN Y., YANG C., HE Y.L., WANG J., LIN A.J. Immobilization of heavy metals in vegetable-growing soils using nano zero-valent iron modified attapulgite clay. Sci. Total Environ. 686, 476, 2019.

6. HUANG L.M., YU G.W., CAI X., LONG X.X. Immobilization of $\mathrm{Pb}, \mathrm{Cd}, \mathrm{Cu}$ and $\mathrm{Zn}$ in a multi-metal contaminated acidic soil using inorganic amendment mixtures. Inter. J. Environ. Res. 11 (4), 425, 2017.

7. ZHANG D., DING A.F. Effects of passivating agents on the availability of $\mathrm{Cd}$ and $\mathrm{Pb}$ and microbial community function in a contaminated acidic soil. Bull. Environ. Contam. Toxicol. 103 (1), 98, 2019.

8. BASHIR S., SHAABAN M., HUSSAIN Q., MEHMOOD S., ZHU J., FU Q.L., AZIZ O., HU H.Q. Influence 
of organic and inorganic passivators on $\mathrm{Cd}$ and $\mathrm{Pb}$ stabilization and microbial biomass in a contaminated paddy soil. J. Soil Sediment. 18 (9), 2948, 2018.

9. JUANG K.W., HO P.C., YU C.H. Short-term effects of compost amendment on the fractionation of cadmium in soil and cadmium accumulation in rice plants. Environ. Sci. Pollut. Res. 19 (5), 1696, 2012.

10. GUO G.H., LEI M., CHEN T.B., YANG J.X. Evaluation of different amendments and foliar fertilizer for immobilization of heavy metals in contaminated soils. J. Soil Sediment. 18 (1), 239, 2017.

11. HAMID Y., TANG L., SOHAIL M.I., CAO X., HUSSAIN B., AZIZ M.Z., USMAN M., HE Z.L., YANG X. An explanation of soil amendments to reduce cadmium phytoavailability and transfer to food chain. Sci. Total Environ., 660, 80, 2019.

12. GU J.F., ZHOU H., TANG H.L., YANG W.T., ZENG M., LIU Z.M., PENG P.Q., LIAO B.H. Cadmium and arsenic accumulation during the rice growth period under in situ remediation. Ecotoxicol. Environ. Saf. 171, 451, 2019.

13. DONG M., ZHAO Y.L., LEI C.X., DAI M.B., YI H.C., KU W.Z. Growth responses and phytoremediation potential of Artemisia selengensis to Cd stress. Acta Sci.Circumst. 32, 1473, 2012 [In Chinese].

14. DONG M., ZHAO Y.L., LEI C.X., ZHOU X.M., KU W.Z. Physiological mechanism of Cd-tolerance of Artemisia selengensis grown in Dongting Lake Wetland. Asian J. Ecotox. 8, 111, 2013 [In Chinese].

15. LI X., ZHANG Y.L., WEI Y.G., XU M.X.,DI G.J., BU D.R. Genotypic differences in $\mathrm{Cd}$ accumulation and translocation in Artemisia selengensis. J. Agro-Environ. Sci. 32, 2132, 2013 [In Chinese].

16. ZHANG D., DING A.F. Effects of combined passivators on remediation of $\mathrm{Cd}$ and $\mathrm{Pb}$ compound-contaminated soil. J Agro-Environ Sci. 37, 2718, 2018 [In Chinese].

17. GILLMAN G.P., SUMPTER E.A. Modification to the compulsive exchange method for measuring exchange characteristics of soils. Aust. J. Soil Res. 24, 61, 1986.

18. HOUBEN D., EVRARD L., SONNET P. Mobility, bioavailability and pH-dependent leaching of cadmium, zinc and lead in a contaminated soil amended with biochar. Chemosphere. 92 (11), 1450, 2013.

19. XU C., CHEN H.X., XIANG Q., ZHU H.H., WANG S., ZHU Q.H., HUANG D.Y., ZHANG Y.Z. Effect of peanut shell and wheat straw biochar on the availability of $\mathrm{Cd}$ and $\mathrm{Pb}$ in a soil-rice (Oryza sativa L.) system. Environ. Sci. Pollut. Res. 25 (2), 1147, 2018.

20. NIGAM N., KHARE P., YADAV V., MISHAR D., JAIN S., KARAK T., PANJA S., TANDON S. Biochar-mediated sequestration of $\mathrm{Pb}$ and $\mathrm{Cd}$ leads to enhanced productivity in Mentha arvensis. Ecotoxicol. Environ. Saf. 172, 411, 2019.

21. CHENG J.Z., Li Y.L., GAO W.C., CHEN Y., PAN W.J., LEE X.Q., Tang Y. Effects of biochar on $\mathrm{Cd}$ and $\mathrm{Pb}$ mobility and microbial community composition in a calcareous soil planted with tobacco. Biol. Fert. Soils. 54 (3), 373, 2018.

22. SUN Y.B., SUN G.H., XU Y.M., LIU W.T., LIANG X.F., WANG L. Evaluation of the effectiveness of sepiolite, bentonite, and phosphate amendments on the stabilization remediation of cadmium-contaminated soils. J. Environ. Manage. 166, 204, 2016.

23. NAMOR A.F.D., GAMOUZ A.E., FRANGIE S., MARTINEZ V., VALIENTE L., WEBB O.A. Turning the volume down on heavy metals using tuned diatomite.
A review of diatomite and modified diatomite for the extraction of heavy metals from water. J. Hazard. Mater. 241, 14, 2012.

24. BIAN R.J., JOSEPH S., CUI L.Q., PAN G.X., LI L.Q., LIU X.Y., ZHANG A.F., RUTLIDGE H., WONG S.W., CHIA C. MARJO C., GONG B., MUNROE P., DONNE S. A three-year experiment confirms continuous immobilization of cadmium and lead in contaminated paddy field with biochar amendment. J. Hazard. Mater. 272,121, 2014.

25. LIU Y.X., WANG Y.Y., LU H.H., LONAPPAN L., BRAR S.K., HE L.L., CHEN J.Y., YANG S.M. Biochar application as a soil amendment for decreasing cadmium availability in soil and accumulation in Brassica chinensis. J. Soil Sediment. 18 (7), 2511, 2018.

26. JIANG P. Research of the growth and quality security of Seleng Wormwood in $\mathrm{Cd}$ polluted soil and the corresponding adjustment measures. Nanjing Agricultural University. 2009 [In Chinese].

27. HAMIDPOUR M., AFYUNI M., KALBASI M., KHOSHGOFTARMANES A.H., INGLEZAKIS V.J., Mobility and plant-availability of $\mathrm{Cd}(\mathrm{II})$ and $\mathrm{Pb}(\mathrm{II})$ adsorbed on zeolite and bentonite. Applied Clay Sci. 48 (3), 342, 2010.

28. SESHADRI B., BOLAN N.S., NAIDU R. Rhizosphereinduced heavy metal (loid) transformation in relation to bioavailability and remediation. J. Soil Sci. Plant Nutr. 15, 524, 2015.

29. ZHANG F., WANG X., YIN D.X., PENG B., TAN C.Y., LIU Y.G., TAN X.F., WU S.X. Efficiency and mechanisms of $\mathrm{Cd}$ removal form aqueous solution by biochar derived from water hyacinth (Eichornia crassipes). J. Environ. Manage. 153, 68, 2015.

30. GAO L.Y., DENG J.H., HUANG G.F., LI K., CAI K.Z., LIU Y., HUANG F. Relative distribution of $\mathrm{Cd}^{2+}$ adsorption mechanisms on biochars derived from rice straw and sewage sludge. Bioresour. Technol. 272, 114, 2019.

31. GUO F.Y., DING C.F., ZHOU Z.G., HUANG G.X., WANG X.X. Stability of immobilization remediation of several amendments on cadmium contaminated soils as affected by simulated soil acidification. Ecotoxicol. Environ. Saf. 161, 164, 2018.

32. XUE Y., GAO B., YAO Y., INYANG M., ZHANG M., ANDREW R.Z., KYOUNG S.R. Hydrogen peroxide modification enhances the ability of biochar (hydrochar) produced from hydrothermal carbonization of peanut hull to remove aqueos heavy metals, batch and column tests. Biochem. Eng. J. 200-202, 673, 2012.

33. ZHENG R.L., CAI C., LIANG J.H., HUANG Q., CHEN Z., HUANG Y.Z., ARP H.P.H., SUN G.X. The effects of biochars from rice residue on the formation of iron plaque and the accumulation of $\mathrm{Cd}, \mathrm{Zn}, \mathrm{Pb}, \mathrm{As}$ in rice (Oryza sativa L.) seedlings. Chemosphere. 89 (7), 856, 2012.

34. YANG X., LIU J.J., MCGROUTHER K., HUANG H.G., LU K.P., GUO X., HE L.Z., LIN X.M., CHE L., YE Z.Q., WANG H.L. Effect of biochar on the extractability of heavy metals $(\mathrm{Cd}, \mathrm{Cu}, \mathrm{Pb}$, and $\mathrm{Zn})$ and enzyme activity in soil. Environ. Sci. Pollut. Res. 23 (2), 974, 2016.

35. SHAHID M., XIONG T.T., MASOOD N., LEVEQUE T., QUENEA K., AUSTRUY A., FOUCAULT Y., DUMAT C. Influence of plant species and phosphorus amendments on metal speciation and bioavailability in a smelter impacted soil, a case study of food-chain contamination. J. Soil Sediment. 14 (4), 655, 2013.

36. KIM R.Y., YOON J.K., KIM T.S., YANG J.E., OWENS G., KIM K.R. Bioavailability of heavy metals in soils, 
definitions and practical implementation--a critical review. Environ. Geochem. Health. 37 (6), 1041, 2015.

37. HE H., NORA F.Y.T., YAO A.J., QIU R.L., LI W.C., YE Z.R. Effects of alkaline and bioorganic passivators on cadmium, lead, zinc, and nutrient accumulation in brown rice and grain yield in acidic paddy fields contaminated with a mixture of heavy metals. Environ. Sci. Pollut. Res. 23, 23551, 2016.

38. ZHAO F.J., MA Y.B., ZHU Y.G., TANG Z., MCGRATH S.P. Soil contamination in China, current status and mitigation strategies. Environ. Sci. Technol. 49, 750, 2015.
39. YU Y., WAN Y.N., WANG Q., LI H.F. Effect of humic acid-based amendments with foliar application of $\mathrm{Zn}$ and $\mathrm{Se}$ on $\mathrm{Cd}$ accumulation in tobacco. Ecotoxicol. Environ. Saf. 138, 286, 2017.

40. LU K.P., YANG X., SHEN J.J., ROBINSON B., HUANG H.G., LIU D., BOLAN N., PEI J.C., WANG H.L. Effect of bamboo and rice straw biochars on the bioavailability of $\mathrm{Cd}, \mathrm{Cu}, \mathrm{Pb}$ and $\mathrm{Zn}$ to Sedum plumbizincicola. Agric. Ecosyst. Environ. 191, 124, 2014. 